Wiley InterScience :: Journal :: Article PDF

Frame contained PDF file, click here to view 


\title{
Communicative Planning - Friend or Foe? Obstacles and Opportunities for Implementing Sustainable Development Locally
}

\author{
Mariann Mannberg** and Elin Wihlborg ${ }^{2}$ \\ ${ }^{1}$ Lulea University of Technology, Sweden \\ ${ }^{2}$ University of Linkoping, Sweden
}

\begin{abstract}
There is a growing understanding of the potential of spatial planning to constitute a co-ordinating arena for sustainable development, and planning processes are expected to merge all dimensions of sustainability. Since the concrete manifestation of spatial planning takes place at a micro level, it all boils down to the need for bringing together stakeholders at municipal level in a well functioning planning processes. Alongside this viewpoint, there is also an increasing awareness of the need for a decentralization of such processes, bringing them closer to the grassroots. Communicative planning is a planning ideal and a theoretical stream that has developed from this new 'paradigm'. It is based on citizen participation as a win-win situation, where the planning process builds a social sustainability, in turn enhancing the likelihood of the process to be successful. However, global and national visions of sustainability and local implementation are in many ways separate from one another. Bringing it further, to the individual level, the gaps are even wider. These gaps make the daily job for the planner increasingly complex and difficult. This article aims to contribute to understanding the characters of these gaps by describing them as four threats. The discussion is purely theoretical and based on the eight proposals of Goodin and Dryzek (2006) on possible pathways from micro-level deliberation towards the macro political system. However, the seed of the discussion is based on the authors' joint experiences from a number of evaluations of planning processes carried out in a Swedish context. Copyright (C) 2007 John Wiley \& Sons, Ltd and ERP Environment.
\end{abstract}

Received 5 October 2006; revised 19 February 2007; accepted 21 February 2007

Keywords: communicative planning; local implementation of sustainable development; deliberative democracy; rationality; legitimacy

* Correspondence to: Mariann Mannberg, Division of Architecture and Infrastructure, Department Of Civil and Environmental Engineering, Lulea University of Technology, SE-976 87 Lulea, Sweden. E-mail: Mariann.Mannberg@Itu.se 


\section{Introduction: Communicative Planning - Function Versus Theory}

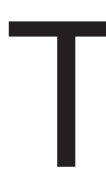

HE ADJUSTMENT TO A MORE SUSTAINABLE SOCIETY REQUIRES THE ABILITY TO CO-ORDINATE A considerable number of different interests in functioning planning processes. Physical planning forms physical settings, and aims to influence, integrate and even educate citizens and other actors. These explicit intentions of communicative planning are often said to enhance democracy (Khakee and Barbanente, 2003). Internationally, participation appears to be the prevailing planning paradigm. Within planning theory, it is described as a transition towards collaborative or communicative planning. It emerges from the ideas of deliberative democracy as participation and public deliberation. Physical planning has a co-ordinating function for sustainable ecological, social and economic development. Participation and co-operation is expected to take place widely between different sectors, but also at different levels - central and local. Planning is founded in the local setting and takes place in the municipality, in most European states and many other countries, and is put forward in the Agenda 2I document as one of the main tools to change society. Chapter Io, for instance, focuses on the ambitions to '... strengthen planning, management and evaluation systems for land and land resources' and its institutional settings, as well as to 'facilitate the active involvement and participation of all concerned, particularly communities and people at the local level, in decision-making on land use and management' (United Nations, 2000-2006).

Communicative planning is characterized by a view of planning as a long-term process in which the focus lies not only on the planning object, but also on the process as such and on communication rather than calculations (Sager, I994). The processes include - and are based on - the citizens' interests and scope for participating. The collaboration with the citizen and other stakeholders thereby becomes a central piece of the planning jigsaw. It is truly a challenge for local communities and municipal political and administrative bodies to implement sustainable development through communicative planning processes. It relates highly to the discourse on deliberative democracy, as we will discuss below.

The validity and the practical potential of communicative planning are in dispute, since it challenges the idea of the competence of professional planners and their municipality-derived authoritative power to plan. The realization of these global and general aims often boils down to a local responsibility, and this article concentrates on four conceptual threats to the local planning and implementation of sustainability.

\section{Aim of the Paper}

We argue that communicative planning favours the ideal of the active and participating citizen, but makes the professional and democratic aspects of the planning process diffuse. First, there is an overwhelming risk that the communicative process will become more in focus than the plan itself. Second, the traditional model of the representative democracy is challenged when new communication is prioritized. As a consequence - and third - the idea of legitimacy is also challenged, and finally, the planning ideal relies on an overreaching idea of consensus rather than political conflict. This article focuses on the ability of communicative planning to serve as a way towards sustainability at a local level. There is an underlying attempt to bring the theoretical and idealistic discourse on communicative planning and deliberative democracy closer to function and practice, and thereby to highlight its differences. Springett and Foster (2005) drop the question '. . . for whom is sustainable development?'. The aim of this article is to elaborate on and develop the four conceptual threats to the local communicative planning processes, regarding sustainability, both from a professional planner perspective and from the point of view of citizens, stakeholders and other actors. Our concluding remarks state how and why communicative planning can be both friend and foe when building an inclusive, sustainable society. 


\section{Local Spatial Planning for Sustainability}

The main 'paradigm' of planning has shifted from rational, synoptic planning, with different planning experts looking at society through separate 'drainpipes'. The planning ideal that is forming today is based on a holistic view of the world, partly sprung from the well known description of sustainable development as a way of meeting our needs without compromising the capacity of the next generation to meet its needs. Sustainability raises new issues in the planning process, even if sustainable development has been considered a metaphor for 'environmental politics gone astray' (Fischer and Hajer, I999; p. 4); however, by basing the concept at the local level and on people's everyday lives, it can gain real meaning and make proper sense. There is a need to integrate different goals of a new society and an objective to merge all dimensions of sustainable development. These changes are contemporary with the general changes when governance replaces government as a general mode of steering and implementing policies (Pierre and Peters, 2000). Policies leaning towards sustainable development are at the core of the governance approach, realized through dialogue, consultation and broad participation in networks. However, governments (both nationally and locally) are still key actors in these processes, and planning towards a sustainable society thus takes place in the interplay between government and governance (Evans, 2005).

\section{Governing Sustainable Planning}

Sustainable development relies on the disputed expression 'our needs'. This is a broad and open concept, which is seldom given practical descriptions based on everyday life experiences. The fundamental global and individual differences built into such a concept certainly make it problematic. Consequently, basic changes must take place in these areas; thus, the municipalities and local communities play a central role in making the world a more sustainable place. However, local implementation of an integrated sustainability perspective is in a poor state. For instance, Shearlock et al. (2000) reveal the situation in the UK by stating that only about $9 \%$ of studied sources expressed an integrated viewpoint, although the sources were targeted as directly dealing with sustainable development.

There is however, a growing awareness of the potential of municipal spatial planning as a common arena for agreements on local development and to limit or promote certain everyday behaviour (Hägerstrand, I99I). Planning takes on a central role in these processes of general social planning, since it relates to physically bound resources such as the use of land, water and air - which are basic prerequisites for humans and all living things. Thus, there is a common planning ideal relying on a bottomup approach (Bogason, 200I). In Sweden, for example, it has been expressed through several government reports and bills. The municipalities and local communities are pinpointed as being the hub of sustainable development, integrating social, economic and environmental issues and actions. In Sweden the municipalities' constitutional exclusive planning power also gives them a unique position in the governmental part of the planning process. The National Board of Housing, Building and Planning (Boverket) emphasizes the role of the comprehensive plan to contextualize single decisions in their own circumstances as a guarantee for an underlying planning process based on 'consultation and transparency' (Hugne and Boverket, I996, p. 7) Planning as such has development as an expression of the general, societal development of democracy towards increasingly broadened cooperation. In western society, past planning ideals have mirrored a more rational way of dealing with new demands from a

${ }^{\mathrm{I}}$ Deliberative democracy as a governmental ideal is expressed in, for example, the Swedish government bill SOU $2005: 36$ and the government report skr 2001/02:I73. 
developing welfare state. Planning today follows trends such as openness and participation - characterizing the late modern network governance (Peters and Pierre, 2004). The demands for increased sustainability are raised in most cases and expected to be integrated into almost all policy areas as a form of mainstreaming. The currently predominant discourse of a shift from government to governance clearly constitutes a context for sustainable development policies and planning. Even if the governments are still clearly visible, they must integrate with other actors in processes of governing at the interface between government and governance (Evans, 2005, p. 2). The new planning ideal focuses on the plan as an outcome, but the process leading to the plan is almost as important. There is a common striving to integrate the basic values of sustainable development into the community and amongst the citizens and local stakeholders by decentralizing the process. By definition, communicative planning is based on communication. Its substance can be described as a cumulative process involving the process itself and achievement of the goal. That is, to achieve the planning goal a functioning communicative process is required; in turn, the process itself provides the means to keep it going. The communicative planning process is based on a broad foundation of representatives from different interests. It is a learning - even fostering - process requiring mutual understanding, integrity, sound judgement and appreciation. This requires the participants to reflect on their own sets of values, not only with regard to the planning issue, but also in terms of interpersonal relations (Khakee, 2005).

There is a built-in ambiguity in the ambition of communicative planning as an idea. Explicitly, planning would be expected to function as a fostering and tutorial process. Only implicitly, if at all, does it have the aim of reaching a planning goal. There is an apparent risk that the process will become 'selfabsorbed' when it is a self-generating goal and receives a superior significance to the planning object as such. If we regard the act of physical planning as a way of concretizing political intentions, politics would then be reduced to being a question of how to handle problems in the planning process. For the single planner, legitimacy is gained by dealing with these problems, for instance, by successfully organizing stakeholder networks (Imrie and Thomas, I999) and the task of the single planner is then to reach a balance between achieving goals and producing a democratic process (Sager, I994).

\section{The Threats!}

Even if the turn towards communicative planning is contemporary with and related to the deliberative turn in democratic theory, they have not explicitly met. Thus we base this argument on the interface of these two broad fields through the four threats. The two social scientific approaches emerge from different fields but their ontological starting points are similar. However, local planning practice and local actions towards increased sustainability are often organized as deliberative innovations such as planning cells or consensus conferences. Goodin and Dryzek (2006) have presented eight proposals on possible pathways for influence from such micro-level deliberation towards the macro political system and its sustainability.

\section{First Threat: Planning for the Process Rather Than the Plan}

The planning process is organized both to give opportunities for different stakeholders to meet and discuss proposals and to generate a formal plan for the future use of the physical setting. Communicative planning focuses on the former aspect of planning; thus, there is a threat that it would degrade the importance of the latter.

We will argue that the first two proposals of Goodin and Dryzek (2006) similarly point to the possibility of 'actually making policy' in a deliberative context and how such a process is taken up into the 
policy process. How, why and when it is taken up into the policy process is a functional prerequisite of communicative planning based on a rather utopian view of the individual's ability to make sound and rational choices and being able to express them, referred to as communicative rationality (Habermas and Cooke, 200I; Sager, 2002). The communicative process is regarded as being dependent on rationality - being the machinery of the process and securing the use of negotiations, and aiming for mutual understanding and agreement (Habermas and Cooke, 200I, p. 6; Faludi, 1986). The notion of rationality (of some kind) in the communicative process has its grounds in the focus on the plan as a legally binding document.

The communicative focus in the planning process raises expectations of the local actors and their community to act rationally in accordance with national and even international goals, such as sustainable development. In reality, however, the everyday choices of individuals, households and stakeholders mainly come from an individual and short-term rationality. Faludi describes rationality as 'comprehensively evaluating possible actions in the light of their consequences' (Faludi, I986, p. II5). Rationality is then subjective and relative to the life of each individual. The rational approach of the plan and its implementation risks being made subordinate to the process, and more closely identified short-term problems will be dealt with before even touching upon basic aims such as global sustainability. Thus, the chains of goals on different levels have to be identified and integrated into all plans, not only into the planning processes. The professional planners are then obliged to contribute to such a perspective to relate the plans and the processes to both global and local sustainability.

Communicative planning has to live with its double aim of achieving the plan as such and also generating the process of co-operation and integration of different interests and actors in the local community. However, such a double approach embraces the traditional division of policy making and public administration. Thus, the democratic ideal is also challenged - not least because this planning approach builds more on the ideas of deliberative democracy.

\section{Second Threat: Challenging the Balance of Power - Decreasing Democracy?}

Policy in societies is made both in formal representative democratic forums and in more deliberative open discussions. The formal democratic process focuses on inclusion, specific positions and resources used to gain power in processes of decision making, and the role of government. The deliberative approach to democracy, on the other hand, focuses on the process of forming ideas and decisions, and the construction of power.

The communicative planning approach relies on the latter view of democracy, but still it often criticizes democracy from the more representative perspective (see, for example, Bengs, 2005). Sager (2005) argues on a theoretical level that when '... planning can be linked to aspects of democracy, it is not a large step to assume that they can also be linked to the broad political development of society'. However, this depends on what form of political development of the society is requested from planning in theory and practice. Goodin and Dryzek (2006) argue from a political-scientific standpoint that there is a need for an informed general public in order to promote deliberative democracy. However, how the general public should be informed and what about is indeed a political question, not least regarding sustainable development. The balance of power in deliberative processes is strongly related to who is expected to construct the truth. The truth has formerly been considered as a professional measurable truth but the communicative approach opens up the issue of trust. The professional planners might lose power through the communicative planning process while other actors in turn gain power and influence on the decision making.

Even if this is not a zero-sum approach to power, it still hints that only if one actor gives up power can others gain - which is not accurate but is still grounds for a threat. Actors can have the power to 
influence planning, but they can only have legitimate power if they have competence and formal roles of taking on power and being accountable, a switching of roles, when they take on obligations other than those they assume according to formal democratic procedure. Thus, they also have to communicate differently and power relations are reconstructed. The formal organized power structures in the democratic organizations are challenged, since power becomes distributed out of the formal organizations and their authorities. In planning regarding sustainability, the planner - who still is localized within the governmental sphere - often takes on a new role, promoting exploitation rather than control and formal decisions (Bengs, 2005). Similarly to Sager (2005, p. 3), we can conclude that decision making in planning processes has been 'depoliticized', since decisions in these cases mainly become an operational management issue rather than a democratic and political consideration. Thus, the accountability for planning and social change is almost invisibly handed over to the single planners. Thereby their professional competence is challenged and democracy can be threatened.

Bengs (2005) argues that the integration of private market interests has a negative effect on communicative planning, and is a consequence of globalization and the decentralization of decision making regarding land use. However, we consider this as an actual political statement of a basic conflict between market and democracy. Amongst others, Goodin and Dryzek (2006, p. 229) argue on the other hand for the use of market testing for policy making in deliberative democracy. Physical planning often relates to market interests, which thereby become key stakeholders in communicative planning processes. However, the argument of being in the hands of the market actors distances itself from democratic power and does not take the obligations and interest provided by the citizens into consideration.

These problems are related to the contextualization of governance rather than the actual government of planning and sustainable development. Planning aims to reach enhanced local sustainability through communicative processes, but this does not automatically mean that it does! By using such expressions, it can be legitimized as doing just this (Bengs, 2005). If new meanings of power distribution and democracy can be constructed in the context of deliberation and governance, even communicative planning could be considered to be democratic and this threat could be conquered.

\section{Third Threat: False Legitimatization?}

Democracy relies heavily on both meanings of legitimacy: legality and trust. The local planning processes take place in legal frameworks settled from above by national governments, as well as by international trends and agreements such as Agenda 2I, but the latter has to be integrated into the values and meanings of the local community by growth of trust, which we recognize as the starting point of the third threat. Based on a European study of local Agenda 2I processes, Evans states that '... legitimizing the new policies of sustainability cannot be forced upon local communities within democratic systems; instead, it is a long-term learning process.' (Evans, 2005, p. 25). Thus, communicative planning and deliberative democracy have to be bottom-up processes, even if they are organized from a semi-hierarchical level. This could promote growth of trust between local actors and legitimizing policy, which is also what Goodin and Dryzek (2006, p. 232) put forward as their fifth proposal. Such building of local trust makes the process more legitimate but it is highly dependent on the actual outcome of the process.

The formal legitimacy (legality) is largely a construction within the government sphere. Communicative planning, as it develops according to governance by collaboration between different stakeholders, citizens and the local governmental structures, creates the more informal legitimacy - trust between actors. The process of communicative planning as confidence building is also what Goodin and Dryzek (2006, p. 234) identify as their sixth proposal. 
Confidence, as an aspect of legitimacy, highlights the two central risks that we see as potential counterproductive effects when more short-term environmental problems and solutions are in focus rather than basic changes towards a more sustainable society. If the participating actors in the communicative planning process mean different things when discussing sustainable development, none of them will reach their aims. The planning process might then lose legitimacy, while not fulfilling anyone's ambition or bridging borders between actors and sectors. It is rather an expression of power, as Sager (2005) points out, when they maintain borders between sectors and do not give up their privilege to define the problem according to the norms of their own sector.

As a consequence of the first threat - planning for the process rather than the plan - there is a risk that the actors will invest more trust in the collaborative process and reach consensus within the process rather than agreeing on the issue as such, and the legitimacy of the plan might be undermined. Goodin and Dryzek (2006, p. 233) identify the risks of the false legitimation when stating that the design 'to legitimize certain policies can sometimes end up legitimizing activist disobedience'. This might also sidestep the professional planner; as Sager (I994, p. I) expresses it, '... planners feel the pulse of injustice and unreason, since their professional field has such close ties to politics'. The legitimating process may end up in a messy understanding of consensus when the process fails to coordinate different interests, undermining both the intent of deliberative democracy and the planning for sustainability.

\section{Fourth Threat: the Ambiguity of Consensus?}

Communicative planning aims to reach consensus, but we will argue that there is an ambiguity of consensus. Consensus is dependent on a subjective assessment by each participating actor, and since there are more possibilities to leave the planning process (exits) the more governance structure it has, the consensus becomes narrower and narrower and less inclusive. However, the exits from the communicative process are closed for the government actors, while being open for other stakeholders. The governmental actors are more or less forced to keep the process together and they are accountable for the undermined democracy, false legitimacy and ambiguity of consensus. Communicative planning has emerged from Habermas' (I984) notion of communicative rationality and its aim to reach consensus. Habermas' division of normative and communicative consensus partly clarifies the ambiguity. Normative consensus signifies unity as a consequence of uncritical adoption of common conceptions, either from manipulation of an elite or from the cultural tradition where the transfer of norms and values is taken for granted. Communicative consensus is in turn based on critical assessment of different alternatives. On behalf of the individual actor, this puts him in 'limbo' between social pressure and individual choice. Critical assessment is based on subjective, individual rationality as discussed above. In this sense, individual rationality can be changed into a goal of reaching consensus, thus leaving the process and losing progress. In a local community with its social network, this assumption is not too far fetched. Collective rationality then turns away from the sustainability task, instead turning towards maintaining or enhancing the social capital of the community. Using communicative planning as an enhancer, or carrier, of democracy is controversial, since consensus is not what characterizes the democratic process. Consensus might act as a legitimizer of the process, providing a smooth ride. According to Sager (I994), the process of communication cannot be intertwined with aiming to achieve consensus. Then the process does not serve as a co-ordinator of interests, but rather as an evoker of transformed opinion. The pure essence of consensus then makes the Habermas distinction between the normative and the communicative sides of it theoretically impossible. At the local level, however, reaching consensus in the process itself might be fruitful and beneficial to the global goal, in the long term reaching a common framework to unite a group without disturbing individual stances concerning the planning issues. 
The pursuit of common consensus through collective rationality might have to be boiled down to striving for successful implementation of how to deal with sustainability in a practical sense, a too-popular oversight that might also end up as the consensus model taking stakeholders as well as professional planners and politicians as hostages, which also are identified as the two final risks of deliberative processes put forward by Goodin and Dryzek (2006).

\section{Concluding Discussion}

There is a need to combine the local and global aims of sustainable development - or in the terms of Goodin and Dryzek to combine micro- and macro-politics - to reach a more sustainable society. These demands are met in both planning theory and communicative planning practice. Communicative planning takes place in the interplay between governance and government, and attempts to give different actors access - and might even equalize their influence on the planning process. To conclude, the four identified threats to sustainable development through communicative planning all challenge the norm of formal democratic governance, and it is clear how they rely on a deliberative understanding of democracy. Planning regarding sustainable development is probably even more threatening, since it is based on diffuse global aims. The first threat we identified, in which the process is discussed as made subordinate to the goal, makes communicative planning a friend of citizens and stakeholders who gain influence, but for the professional planner and the local politicians who have to be accountable it is likely to be a foe. The second threat to democracy and power makes communicative planning a friend of all strong actors and a foe of those in less favourable positions. The more informed the public is, and the more the market actors have aims similar to the public (hopefully on sustainable development), the more communicative planning will be a friend of all. However, this closely relates the capacity of building trust and legitimacy through the process and the outcome as a formal binding plan. Thus our analysis indicates that this is an important part of the communicative planning process and has to be taken seriously. As long as the idea of democracy is diffuse, the legitimating process will also be diffuse and the risk of false legitimizing remains. Similar threats emerging from ambiguity of consensus might hide conflicts, thereby (again) making communicative planning the friend of the strong actors. The planning process must co-ordinate all four threats and not let any of them overturn the process to reach sustainability. The geographer Hägerstrand formulates the same when writing that sustainable development relies on our ability

... to make future contract with nature, supplementing the social contract, is precisely a matter of establishing norms. Right behaviour must become self-evident (Hägerstrand, 2000, p. 3I4).

There are few if any good alternatives to communicative and deliberative processes to reach sustainable development, because of the tight connection between our everyday lives and the effect of humans on the environment. Thus, there is a need to continue the planning and research in the interface of politics, to keep up the struggle for a more sustainable society in the daily life of each and every one of us. Communicative planning becomes the friend of governance structure and deliberative approaches, since they all have similar roots. As long as the government structure is forced to take on democratic accountability, however, it will consider communicative planning as a foe. If or when the bases of democracy and legitimacy gain new meanings in relation to their new context then communicative planning may be seen as the friend of reaching a more sustainable society at all levels. 


\section{Acknowledgment}

The work undertaken for this article forms part of the research program Sustainable Households, which is funded by the Swedish Environmental Protection Agency (SEPA). The views expressed in the paper reflect only those of the authors.

\section{References}

Bengs C. 2005. Planning theory for the naive? European Journal of Spatial Development. www.nordregio.se/EJSD/miscellanous, July.

Bogason P. 200I. Public Policy and Local Governance. Institutions in Postmodern Society. Elgar: Cheltenham.

Evans B. 2005. Governing Sustainable Cities. Earthscan: Sterling, VA.

Faludi A. I986. Critical Rationalism and Planning Methodology. Pion, corp: London.

Fischer F, Hajer MA (eds). I999. Beyond global discourse: the rediscovery of culture. In Environmental Politics. Living with Nature. Oxford University Press: Oxford. pp. I-20.

Goodin R, Dryzek J. 2006. Deliberative impacts: the macro-political uptake of mini-publics. Politics and Society 34(2): 219-244.

Habermas J. I984. The Theory of Communicative Action. Polity: Cambridge.

Habermas J, Cooke M. 200I. On the Pragmatics of Communication. Polity: Cambridge.

Hägerstrand T. I99I. What about people in regional science? Om Tidens Vidd och Tingens Ordning, Carlestam G, Sollve B (eds). Statens råd för Byggnadsforskning: Stockholm.

Hägerstrand T. 2000. Narratives and computations. In Knowing and Doing. On Knowledge and in Environmental Protection, Lundgren LJ (ed.). Swedish Environmental Protection Agency Stockholm; 307-315.

Hugne K, Boverket. I996. Boken om Översiktsplan. Boverket: Karlskrona.

Imrie R, Thomas H. I999. British Urban Policy: an Evaluation of the Urban Development Corporations. Sage: London.

Khakee A. 2005. Samhällsplanering: Nya Mål, Perspektiv och Förutsättningar. Studentlitteratur: Lund.

Khakee A, Barbanente A. 2003. Negotiative land-use and deliberative environmental planning in Italy and Sweden. International Planning Studies 8(3): I8I-200.

Peters G, Pierre J (eds). 2004. Multi-Level Governance and Democracy: a Faustian Bargain? Oxford University Press: Oxford.

Pierre J, Peters G. 2000. Governance, Politics and the State. Macmillan: London.

Sager T. 1994. Communicative Planning Theory. Avebury: Aldershot.

Sager T. 2002. Democratic Planning and Social Choice Dilemmas: Prelude to Institutional Planning Theory. Ashgate: Aldershot.

Sager T. 2005. Communicative planners as naive mandarines of the neo-liberal state? European Journal of Spatial Development. www.nordregio.se/EJSD/miscellanous, December.

Shearlock C, James P, Phillips J. 2000. Regional sustainable development: are the new regional development agencies armed with the information they require? Sustainable Development 8: 79-88.

Springett D, Foster B. 2005. Whom is sustainable development for? Deliberate democracy and the role of unions. Sustainable Development I3: 27I-28I. 